\title{
Relationship Of Patient Characteristics With Compliance With Lifestyle Modifications In Recovery Post Diabetes Mellitus Patients
}

\author{
Isnayati 1*, Ricky Rianto Ichsan,2, Sri Atun Wahyuningsih ${ }^{3}$ \\ 1,2,3, Akademi Keperawatan Pelni Jakarta, Indonesia ${ }^{1}$
}

*Corresponding Autor : pelniisnayati@yahoo.com

\begin{abstract}
Diabetes mellitus is a group of metabolic diseases with hyperglycemic characteristics that occur due to abnormal insulin secretion, insulin action or both. In managing the disease, the patient's role is very important, especially in terms of increasing adherence in establishing therapy in order to achieve optimal blood glucose levels to prevent more severe complications. Objective The relationship between patient characteristics and the level of adherence to lifestyle modification in the recovery of patients after DM Method This research is analytical research with cross sectional approach. This research was conducted in the Pelni Hospital Room in Jakarta in May 2017. The population was all patients with diabetes mellitus who came to the Pelni Hospital room. Sampling using a consecutive sampling technique with a total sample of 65 people. Primary data collection instruments using DM risk factor questionnaire. Results of the study In this study respondents who were the subject of the study were Diabetes Mellitus sufferers who visited the Pelni Hospital Inpatient Room Jakarta. Differences in characteristics possessed by each patient, can indirectly affect patient compliance in taking drugs. In table 1 it can be seen that in the age group below 45 years have a higher compliance that is equal to $70.0 \%$ compared to the age group above 45 years which is $25.5 \%$. This shows the tendency between patient compliance in taking diabetes medications, where the younger the patient's age, the more likely it is to be obedient in consuming diabetes medications. Conclusion Based on the results of the study it can be concluded that there is a significant relationship between the age and level of education of patients with the level of adherence in undergoing treatment. However, there is no significant relationship between the sex of the patient and the level of adherence in undergoing treatment.
\end{abstract}

Keywords: Characteristics, Compliance Level, Diabetes Mellitus

\section{INTRODUCTION}

Diabetes mellitus is a group of metabolic diseases characterized by hyperglycemia that occurs due to abnormalities in insulin secretion, insulin action or both. Currently, infectious disease epidemics appear to be the biggest cause of death in Indonesia, while infectious disease epidemics have not yet been completed. Based on the latest epidemiological studies, Indonesia has entered into an epidemic of type 2 diabetes mellitus. Changes in lifestyle and urbanization appear to be important causes of this 
problem. It is estimated that around 50\% of people with diabetes are undiagnosed in Indonesia. In addition, only two-thirds of those diagnosed underwent treatment, either pharmacological or non-pharmacological. Of those who underwent the treatment, only a third were well controlled. Evidence shows that diabetes complications can be prevented with optimal glycemic control. However, in Indonesia, glycemic control has not been achieved.

Various epidemiological studies have shown a tendency to increase the incidence and prevalence of type 2 diabetes in various parts of the world. WHO predicts a substantial increase in the number of people with diabetes in the coming years. WHO predicts an increase in the number of DM sufferers in Indonesia from 8.4 million in 2000 to 21.3 million in 2030.1 in fact, from 2007 to 2013 there was an increase in DM sufferers, from $1.1 \%$ to $2.1 \%$. In Bali, the prevalence of DM patients diagnosed by health workers in 2013 was $1.5 \%$.

At the Tembuku 1 District Health Center, in 2014 DM disease was ranked 5th with a prevalence of $7 \%$ of the total visits to the puskesmas. The number of patients recorded in 2014 was 177 patients. Diabetes mellitus is a chronic disease that will last a lifetime. In managing the disease, apart from health workers, the role of patients and their families is very important, especially in terms of increasing adherence to therapy in order to achieve optimal blood glucose levels. By achieving optimal blood sugar levels, it can indirectly prevent DM sufferers from experiencing more severe complications, so that the quality of human resources can still be maintained.

Diabetes mellitus is a disease that cannot be cured, but can be controlled. Therapy in diabetes mellitus is carried out for life and requires compliance from the patient to control the disease. In the Pelni Hospital Jakarta Ward, there is no data regarding the level of compliance with DM patients undergoing treatment. There are several things that affect patient adherence, namely the demographic condition of the patient which includes age, gender and level of education.

\section{MATERIAL AND METHODS}

This research uses analytical research with cross sectional approach. This research was conducted in the Pelni Hospital Jakarta Ward in May 2017. The research population used was diabetes mellitus patients who came to the Pelni Hospital Jakarta ward from 11 April to 31 May 2017. Blood sampling in this study used a consecutive sampling technique, namely Diabetes Mellitus patients who came to the Pelni Hospital Jakarta 
inpatient room from April 11 to May 31, 2017. The number of respondents that must be obtained is 65 people using the sample formula. The inclusion criteria in this study were people with Diabetes Mellitus who had been diagnosed and were willing to become respondents. Subjects in the study were excluded if the subject refused to be included in the study, the subject was unable to participate in the study (communication barriers, mental disorders, mental retardation, and other conditions that resulted in difficulty in obtaining data), the subject experienced decreased consciousness, dementia and with psychotic symptoms. , the subject immigrates outside the village or dies. In this study, several instruments were used in the form of a questionnaire to determine the age, gender and educational level of the research subjects. The level of adherence in patients can be measured using the Medication Adherence Questionnaire (MAQ).

The MAQ questionnaire is a validated adherence assessment tool and is often used to assess treatment adherence to patients with chronic diseases, such as diabetes mellitus. The MAQ contains four questions about drug use with yes and no answers. A high MAQ value indicates a low level of patient adherence to treatment. The data obtained will be analyzed to determine the relationship between the characteristics of the respondents and the level of adherence in undergoing treatment. Data analysis used Chi Square test with SPSS version 16.0 program with a significance level of $\mathrm{p}<0.05$.

\section{RESULTS}

Table 1. Results of Data Analysis

\begin{tabular}{lccc}
\multicolumn{1}{c}{$\begin{array}{c}\text { Respondent } \\
\text { Characteristics }\end{array}$} & \multicolumn{2}{c}{ Compliance Level } & P Value \\
\cline { 2 - 4 } Age & Obey & Not obey & \\
$\leq 45$ Year & 7 & 3 & 0,018 \\
$>45$ Year & 14 & 41 & \\
\hline Gender & 9 & & 0,531 \\
Male & 12 & 24 & \\
Female & & 20 & 0,009 \\
\hline Level Of Education & 8 & 37 & \\
Low & 13 & 7 & \\
High & & & \\
\hline
\end{tabular}


Based on the research data in table 1 it can be seen that the higher the age of the patient, the less obedient the patient to pharmacological treatment. At the age $<45$ years, the level of adherence is $70 \%$ and at the age $>45$ years the adherence rate is $25.5 \%$. In addition, from the analysis test, it was found that there was a significant relationship between age and the level of compliance of patients in Pelni Hospital Jakarta Hospital in undergoing treatment $(\mathrm{p}=0.018)$. From this it can be concluded that the younger the patient, the more obedient in carrying out pharmacological treatment for diabetes mellitus. This is not in accordance with the literature review which states that the higher the age of a person will increase adherence to treatment. However, this is consistent with the Hannan researcher, where Hannan concluded that patients with a smaller age may have a higher level of adherence to pharmacological treatment.

There is also a difference in the level of adherence based on sex between men and women where it was found that women had a higher level of adherence, namely $37.5 \%$ when compared to men, namely $27.3 \%$ in carrying out pharmacological treatment for diabetes mellitus. The results of the analysis test stated that there was no significant relationship between gender and the level of adherence in undergoing treatment ( $p=$ 0.531). This is different from the research conducted by Hannan, where Hannan concluded that men had a higher level of adherence to pharmacological treatment than women.

Based on the level of education, the results of the highest adherence were found in patients who attended education up to tertiary institutions, which was $66.7 \%$ and those who had the lowest level of adherence to patients who did not attend primary school where only had an adherence rate of $4.8 \%$. In addition, the results of the SPSS analysis test also stated that there was a significant relationship between the level of education and the level of adherence to treatment $(p=0.009)$. From these data it can be concluded that the higher the level of education of a person, the more obedient the person is to follow pharmacological treatment of diabetes mellitus. This is consistent with the research conducted by Hannan, where Hannan concluded that the higher a person's education level, the higher the level of compliance with pharmacological treatment in patients. Patient non-compliance increases the risk of complications and worsening the disease.

The success of therapy can be seen from a decrease in fasting blood sugar levels and an increase in the quality of life of patients so that complications are avoided. The success 
of therapy is influenced by compliance, motivation, and family support. The success of diabetes mellitus therapy can be increased by regulating diet, monitoring blood sugar levels, maintaining foot hygiene and exercise portions. Another study also found that the decrease in blood sugar levels was greatly influenced by physical exercise (exercise) with a decrease reaching 30.14\%. Apart from adherence to drug use, education level and history of obesity also greatly influence the success of therapy.

\section{DISCUSSION}

Based on the research data above, it can be seen that the higher the age of the patient, the less obedient the patient is to pharmacological treatment. At the age $<45$ years, the level of adherence is $70 \%$ and at the age $>45$ years the adherence rate is $25.5 \%$. In addition, from the analysis test, it was found that there was a significant relationship between age and the level of compliance of patients in Pelni Hospital Jakarta Hospital in undergoing treatment $(\mathrm{p}=0.018)$. From this it can be concluded that the younger the patient, the more obedient in carrying out pharmacological treatment for diabetes mellitus. This is not in accordance with the literature review which states that the higher the age of a person will increase adherence to treatment. However, this is consistent with the Hannan researcher, where Hannan concluded that patients with a smaller age may have a higher level of adherence to pharmacological treatment.

There is also a difference in the level of adherence based on sex between men and women where it was found that women had a higher level of adherence, namely 37.5\% when compared to men, namely $27.3 \%$ in carrying out pharmacological treatment for diabetes mellitus. The results of the analysis test stated that there was no significant relationship between gender and the level of adherence in undergoing treatment ( $p=$ 0.531). This is different from the research conducted by Hannan, where Hannan concluded that men had a higher level of adherence to pharmacological treatment than women.

Based on the level of education, the results of the highest adherence were found in patients who attended education up to tertiary institutions, which was $66.7 \%$ and those who had the lowest level of adherence to patients who did not attend primary school where only had an adherence rate of $4.8 \%$. In addition, the results of the SPSS analysis test also stated that there was a significant relationship between the level of education and the level of adherence to treatment $(p=0.009)$. From these data it can be concluded that the higher the level of education of a person, the more obedient the person is to 
follow pharmacological treatment of diabetes mellitus. This is consistent with the research conducted by Hannan, where Hannan concluded that the higher a person's education level, the higher the level of compliance with pharmacological treatment in patients. Patient non-compliance increases the risk of complications and worsening the disease. The success of therapy can be seen from a decrease in fasting blood sugar levels and an increase in the quality of life of patients so that complications are avoided. The success of therapy is influenced by compliance, motivation, and family support. The success of diabetes mellitus therapy can be increased by regulating diet, monitoring blood sugar levels, maintaining foot hygiene and exercise portions. Another study also found that the decrease in blood sugar levels was greatly influenced by physical exercise (exercise) with a decrease reaching 30.14\%. Apart from adherence to drug use, education level and history of obesity also greatly influence the success of therapy.

\section{CONCLUSION}

Based on the results of the study, it can be concluded that there is a significant relationship between age and education level of patients with the level of adherence to treatment. However, there was no significant relationship between the sex of the patient and the level of adherence to treatment. Biased advice is to provide more in-depth counseling to diabetes mellitus sufferers during visits about the importance of adherence in undergoing therapy and it must be remembered that adherence to drug use is only one of the factors that influence the success of therapy.

\section{REFERENCES}

Dewi. I. A. P., Faktor-Faktor Yang $\quad$ Mempengaruhi Keberasilan Terapi $\quad$ Pada PenderitaDiabetes Miletus (Suatu Studi Penderita Diabetes Mellitus Bulan Oktober 2009 Di RSD. SOEBANDI, Jember), Skripsi, Falkutas Kedokteran Kedokteran, Universitas Jember. 2009.

Febriana, R. Hubungan Kepatuhan Diit Dengan Kadar Gula Darah Sewaktu Pada Pasien Diabetes Mellitus Tipe 2 Di Rawat Inap Rsud Sukoharjo. Surakarta. Falkutas Kedokteran Universitas Muhamadiyah. 2014.

Hannan M. Analisis Factor Yang Mempengaruhi Kepatuhan Minum Obat Pada Pasien Diabetes Mellitus Di Puskesmas Bluto Sumenep. Wijaya Medika. 2013. 
PERKENI. 2011. Consensus Pengelolahan Dan Perencanaan Diabetes Mellitus Tipe 2 Di Indonesia. Jakarta.

Pratita, N.D. Hubungan Dukungan Pasangan Dan Health Locus Of Control Dengan Kepatuhan Dalam Menjalani Proses Pengobatan Pada Penderita Diabetes Mellitus Tipe 2, Jurnal Ilmiah Mahasiswa, Universitas Surabaya, 1(1). 2012

Puji I., Heru S. \& Agus S. Pengaruh Latihan Fisik; Senam Aerobic Terhadap Penurunan Kadar Gula Darah Pada Penderita DM Tipe 2 Di Wilayah Puskesmas Bukateja Purbolingga, Media Ners, 1(2), 49-99. 2007.

Puskesmas Tembuku 1. Profil Puskesmas Tembuku 1 Tahun 2014. Bangle . 2015.

Santosa, M. Pengenalan Penyakit DM \& Penanganannya Dewasa Ini, http://www.pbpapdi.org/papdi.php?pb=det Il_Berita\&Kd_Berita=87 